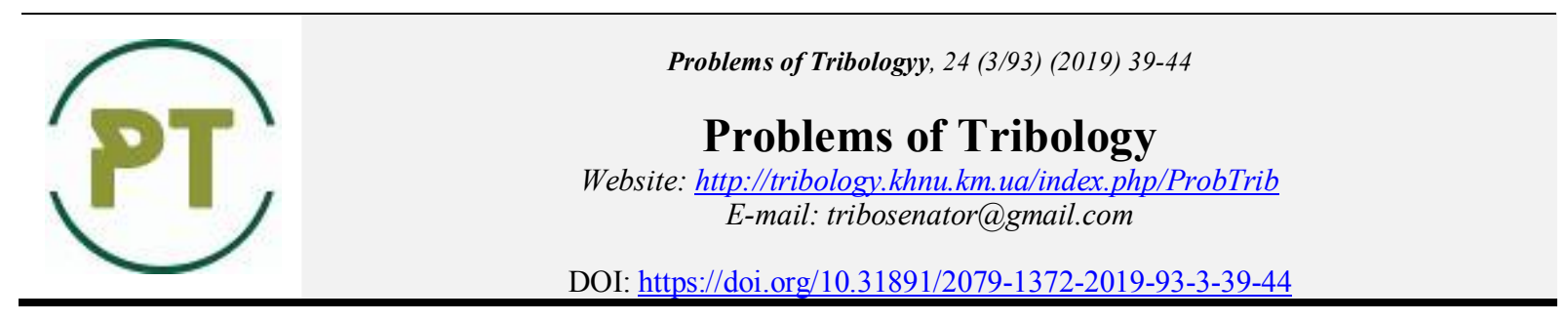

\title{
Analysis of the influence of nitriding in a glow discharge on the properties of a titanium alloy
}

\author{
N.S. Mashovets * \\ Khmelnitskyi National University, Ukraine \\ *E-mail:mashovetsns@ukr.net
}

\begin{abstract}
This work is devoted to the results of the low-temperature temperature hydrogen-nitriding in glow discharge to develop recommendations for further practical application. Surface modification of titanium alloys were carried out by low-temperature nitriding in a glow discharge in hydrogen-free environment. The main advantage of this method lies in the absence of hydrogen embrittlement and complete environmental safety process. Application of the glow discharge can not only speed up the process by the order of the diffusion surface saturation with nitrogen, but also significantly alters the kinetics of the process and quality of the nitrided layer, in particular its physio-mechanical properties and phase composition.
\end{abstract}

Keywords: titanic alloy, nitriding in glow discharge, friction and wear.

\section{Introduction}

In high-tech industries, light metal materials are widely used, which work in conditions of intensive wear. Titanium and its alloys are used in many fields due to their useful properties such as low specific weight, low modulus of elasticity, high corrosion resistance. However, low wear resistance of these materials under conditions of boundary and abrasive friction can't be used in the industries without hardening the surface. Currently, there are many ways of hardening titanium surface: Ion implantation, laser hardening, nitriding, PVD and CVD coating techniques, the creation of surface nanostructures.

Traditionally, surface modification of titanium alloys by glow discharge nitriding was carried out at a relatively high temperature and in atmospheres containing hydrogen [1, 2]. However, the surface layer becomes brittle, which greatly narrows the range of practical uses of the technology. When low-temperature hydrogennitriding in glow discharge is formed on the surface of a relatively thin layer of nitride structures and there is a relatively small depth of the diffusion zone. However, due to the greater plasticity of the surface layer, new opportunities open up for the use of the modified titanium alloys in a variety of industries.

Operational characteristics of titanium alloys defined physical-mechanical characteristics of the surface and their phase composition, which depend on the process parameters of nitriding. To intensify the process of strengthening the surface of titanium alloys promising method of low-temperature hydrogen-nitriding in glow discharge. The main results on the development of scientific foundations of industrial technologies and equipment for the implementation of the nitriding process were performed by the schools of Yu.M. Lahtina and B.M. Arzamasov. The basics of the theory and practice of hydrogen-nitriding in glow discharge were developed by V.G. Kaplun and I.M. Pastukh [3, 4].

\section{Methods and results of research}

Surface modification of titanium alloys were carried out by low-temperature nitriding in a glow discharge in hydrogen-free environment. The main advantage of this method lies in the absence of hydrogen embrittlement and complete environmental safety process. Experimental set - UATR-1 nitriding in a glow discharge in hydrogen-free environments was developed in Khmelnytsky National University. The installation includes the discharge chamber vacuum system, the preparation of the gaseous medium, and power supply and management. The latter was primarily designed to maintain the glow of electric discharge in the gas and at least short-term exclusion of its transition to the arc. 
Technical characteristics of the installation:

- Power $40 \mathrm{~kW}$;

- Three-phase alternating current, $50 \mathrm{~Hz} 380 \mathrm{~V}$;

- The maximum voltage in the cell $1500 \mathrm{~V}$;

- The diameter of the vacuum chamber $600 \mathrm{~mm}$;

- The height of the vacuum chamber $1000 \mathrm{~mm}$;

- Minimum vacuum of $1 \mathrm{~Pa}$;

- Operating temperature range $400-1100^{\circ} \mathrm{C}$;

- Maximum weight of $500 \mathrm{~kg}$ cages.

There was control over the composition of the gaseous medium, the temperature, the pressure in the discharge chamber, the voltage on the electrodes and the current camera therein ( respectively - the current density ) during the process. As noted above, a feature of the installation is to use a hydrogen-free gas mixture. However, the absence of hydrogen, which is a reducing metal and neutralizes oxygen requires especially pure gas $(99.9 \%)$ and a completely sealed gas supply system and vacuum chamber. Even a small amount of oxygen $(0.1 \%)$ causes the formation of oxides on a metal surface and greatly reduces the efficiency of the process up to its total cessation. Therefore, in contrast to systems that operate with hydrogen- saturating fluids (ammonia, a mixture of nitrogen and hydrogen), this unit has separators for oxygen and moisture.

Application of the glow discharge can not only speed up the process by the order of the diffusion surface saturation with nitrogen, but also significantly alters the kinetics of the process and quality of the nitrided layer, in particular its physio-mechanical properties and phase composition. This allows for the optimization of the mechanical properties of the surface layer depending on the operating conditions of structural elements and also improves their wear resistance.

For research purposes, the standards from an $\alpha+\beta$ alloy were used. Ionic nitriding was conducted after different regimes, the technological parameters of the process were varied in such scopes: temperature $\left(\mathrm{T}^{0} \mathrm{C}\right)$ within the limits of $540-700^{\circ} \mathrm{C}$, pressure $(\mathrm{P}, \mathrm{Pa})$ - 80- $400 \mathrm{~Pa}$, time (min) - 20-240 min, maintenance of argon (Ar \%) - 0-96\%. Research of fretting-resistant titanic alloy Ti-Al6-Cr2-Mo2,5 were conducted on the special options which are described in work [5].

Tribological researches were conducted on the universal machine of friction UMF 2168 applying the method described in work [6], according to the of chart the disk-finger with the spherical surface of standard $\mathrm{R}$ 2,5 , in the conditions of dry friction. Counter-body the disk is the hardened steel 45 (HRC-45). Speed of disk rotation is $40 \mathrm{~m} / \mathrm{min}$., loading is about $20 \mathrm{~N}$. Research was conducted in uninterrupted mode and the following parameters of friction were fixed by means of computer: size of linear wear with accuracy calculation of 0,5 $\mathrm{mcm}$ in scopes from 0 to $600 \mathrm{mcm}$, moment of friction, middle temperature in the zone of contact with measuring discreteness through $0,5 \mathrm{sec}$.

Comparative studies of the effect of the nitrided layer on tribological properties and on the wear pattern of the nitrous and non-nitrous titanium alloy surfaces were conducted. The influence of technological parameters of the process in the smoldering discharge on the intensity of wear and the coefficient of friction of the samples nitrided under different modes was investigated. Modes of nitriding and characteristics of the surface layers of the samples are shown in table 1.

Characteristics of VT8 Nitrogen Alloy Samples

Table 1

\section{Characteristics of VT8 Nitrogen Alloy Samples}

\begin{tabular}{|c|c|c|c|c|c|c|c|c|c|}
\hline \multirow{2}{*}{ 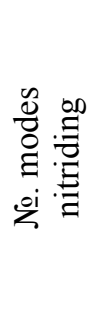 } & \multicolumn{2}{|c|}{$\begin{array}{l}\text { Nitrogen mode } \\
\text { settings }\end{array}$} & \multirow{2}{*}{ 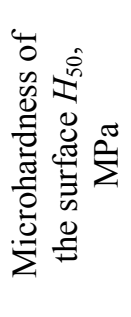 } & \multirow{2}{*}{ 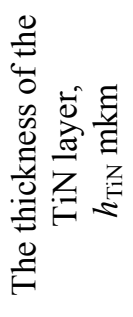 } & \multirow{2}{*}{ 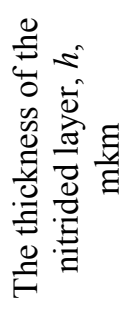 } & \multicolumn{2}{|c|}{$\begin{array}{l}\text { The phase } \\
\text { composition of the } \\
\text { nitrided layer, \% }\end{array}$} & \multirow{2}{*}{ 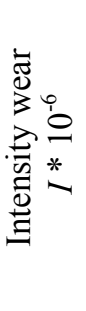 } & \multirow{2}{*}{ 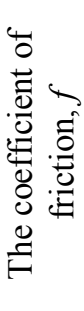 } \\
\hline & 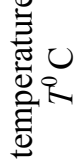 & 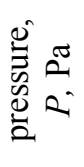 & & & & TiN & $\mathrm{Ti}_{2} \mathrm{~N}$ & & \\
\hline 1 & 660 & 320 & 6500 & 1,6 & 75 & 5,9 & 19,2 & 0,22 & 0,32 \\
\hline 2 & 580 & 320 & 5700 & 1,7 & 60 & 2,6 & 18,6 & 0,20 & 0,29 \\
\hline 3 & 660 & 160 & 7300 & 2,5 & 80 & 2,2 & 21,6 & 0,21 & 0,31 \\
\hline 4 & 580 & 160 & 6400 & 2,3 & 65 & 0 & 22,3 & 0,19 & 0,29 \\
\hline 5 & 560 & 240 & 6500 & 1,8 & 40 & 0 & 21,8 & 0,17 & 0,27 \\
\hline 6 & 680 & 240 & 7000 & 2,6 & 95 & 7,8 & 25,4 & 0,23 & 0,40 \\
\hline 7 & 620 & 125 & 7200 & 2,8 & 85 & 2,1 & 24,1 & 0,19 & 0,30 \\
\hline 8 & 620 & 355 & 5900 & 2,5 & 50 & 5,5 & 11,5 & 0,16 & 0,26 \\
\hline 9 & 620 & 240 & 6350 & 2,7 & 60 & 3,8 & 20,3 & 0,12 & 0,20 \\
\hline \multicolumn{3}{|c|}{ Not nitrous } & 4400 & - & - & - & - & 8,5 & 0,6 \\
\hline
\end{tabular}


The formation of solid layers on the surface of the titanium alloy saved leads to an increase in wear resistance, which gradually decreases along the depth of the nitrided layer. X-ray diffraction studies have shown that as a result of low-temperature nitriding, the titanium alloy VT8 produces TiN mononitride $(\delta$ phase) and $\varepsilon-\mathrm{Ti}_{2} \mathrm{~N}$ phase (Fig. 1). The presence of $\varepsilon-\mathrm{Ti}_{2} \mathrm{~N}$ nitride on the surface and a solid solution of $\alpha$-TiN promotes an increase in antifriction properties and a decrease in the coefficient of friction and wear rate. At the same time, the lowest temperatures occurred in the friction zone. When a solid and brittle $\delta$-phase TiN is formed on the surface, the wear mechanism of the material changes from redox to abrasive, which is caused by an increase in the temperature in the contact zone, the coefficient of friction and the intensity of wear.

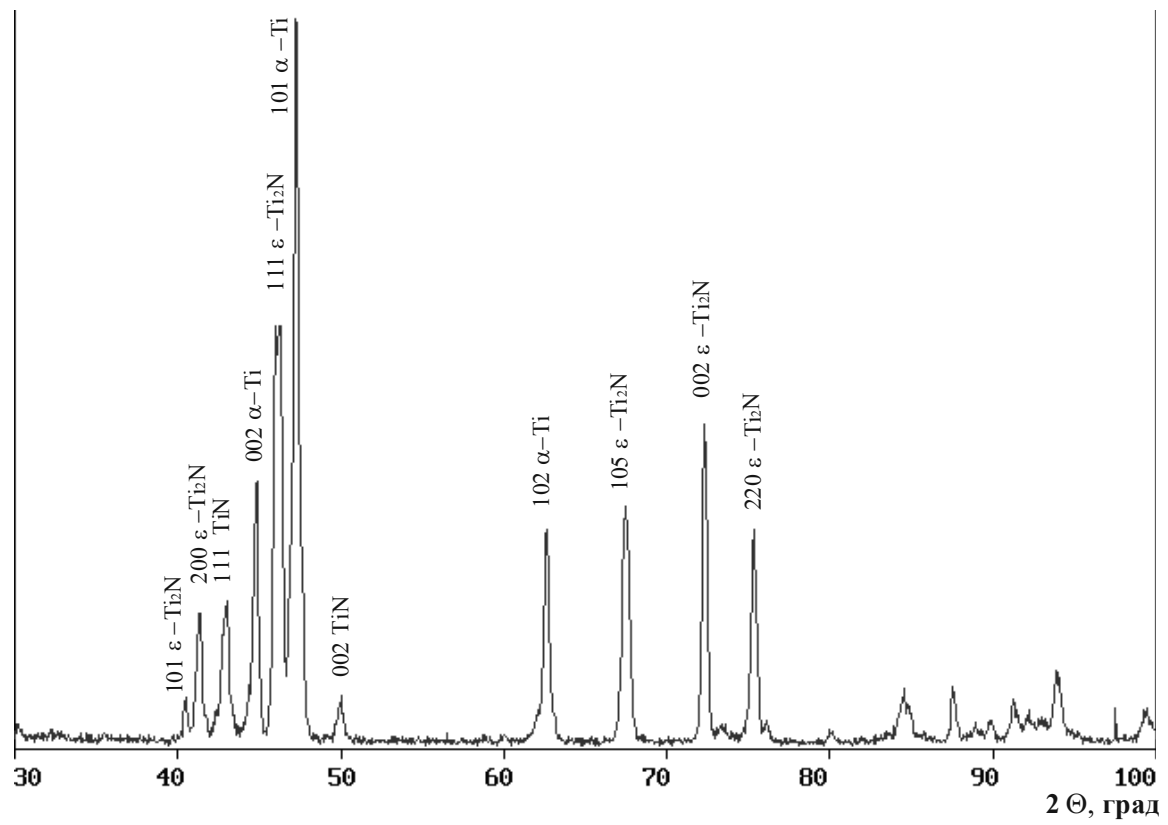

Fig. 1. X-ray diffraction patterns of nitrided titanium alloy VT8

The study of the dependence of the wear on the friction path of the nitrided and non-nitrided titanium alloys showed that the non- nitrided samples wear intensively. The value of their wear in the test conditions was $0.4 \mathrm{~mm}$ after $170 \mathrm{~m}$ of sliding path. The wear rate was $8.5 \cdot 10^{-6}$. After wear of the nitrided layer the magnitude of wear of the titanium alloy increases sharply (Fig. 2).

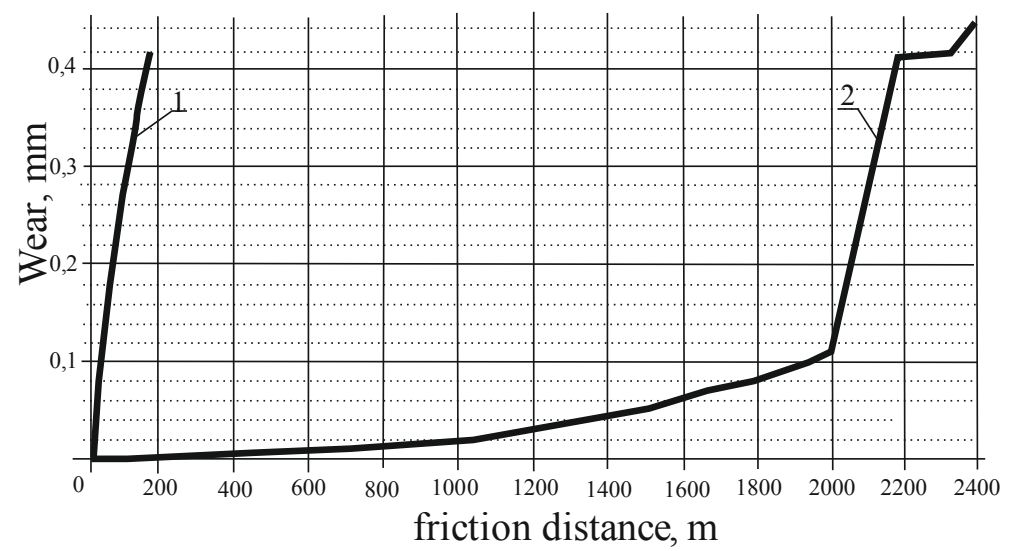

Fig. 2. Correlation between of wear and way in:

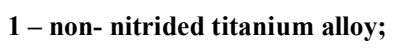

In Fig. 3 shows cross-sections of friction tracks of non- nitrided and nitrided samples, which show that the non- nitrided sample has a much larger amount of wear (friction track depth). Under the influence of normal loading, plastic deformation occurs in the process of wear on the friction track, which changes the size and shape of the grains, which increases the surface hardness by 100-200 MPa. The surfaces of the friction of the sample and the countertile after tribological studies have tracks in the form of furrows, which is formed as a result of the adhesive interaction of a nitrated titanium alloy with a steel surface (Fig. 4). 

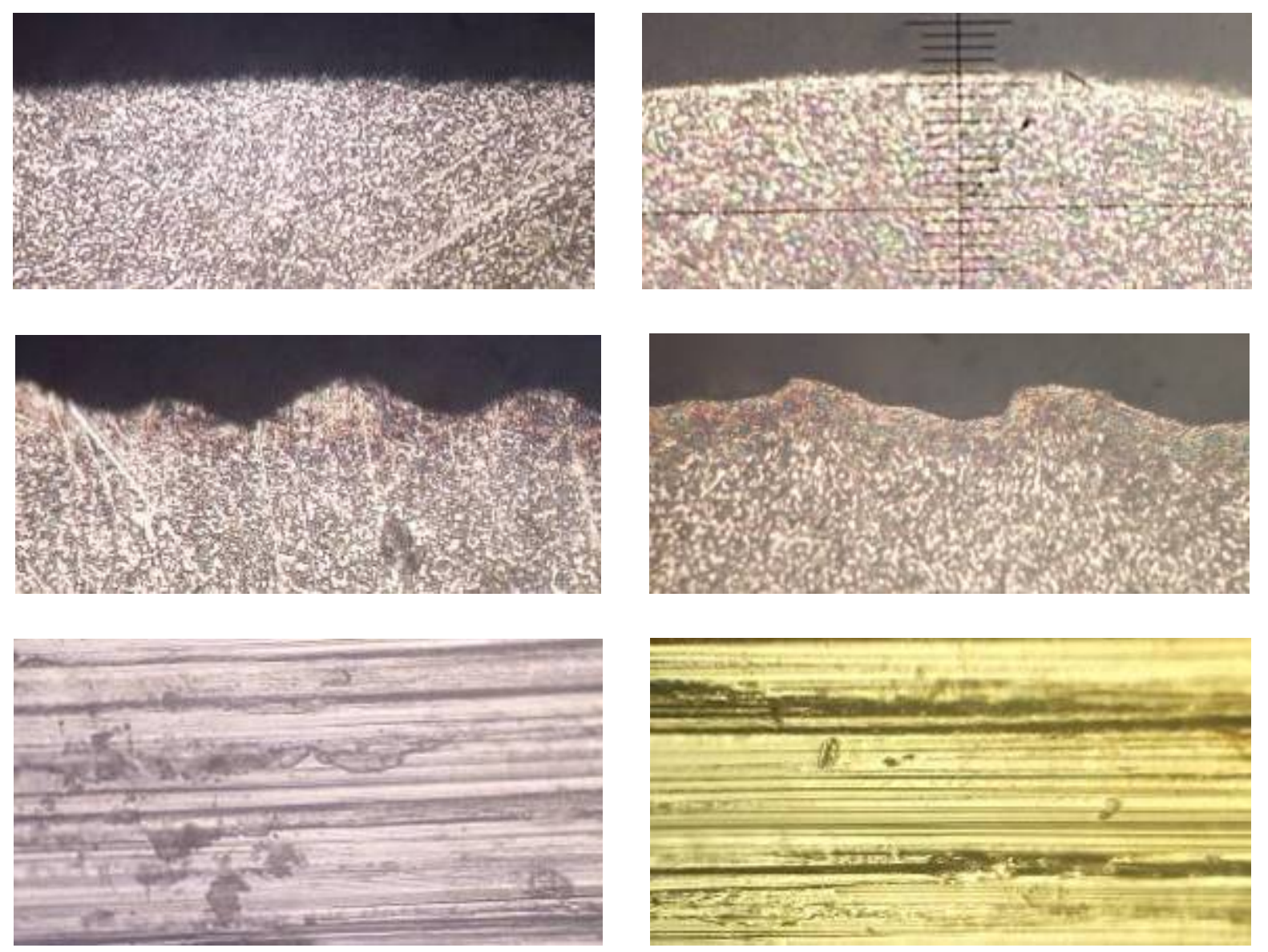

a

Fig. 3. The friction path in cross section:

a - non- nitrided titanium alloy VT8;

b - after nitriding under load $20 \mathrm{~N}$ (x800)
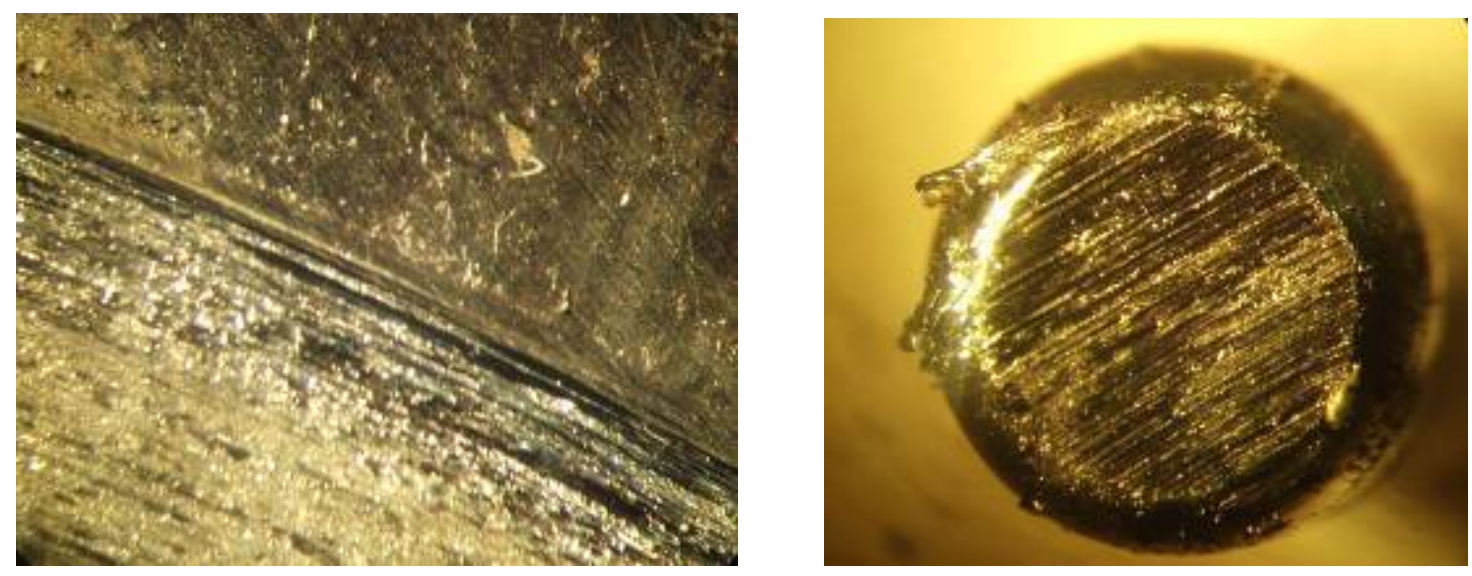

Fig. 4. The surfaces of the friction of the sample and the countertile after tribological studies

In order to study the magnitude of the clamping force of the titanium alloy after nitriding in the glow discharge, the wear value of the friction pair "n nitrided titanium alloy - steel hardened ShH15" studies of samples of VT8 alloy, nitrided in the mode $T=680^{\circ} \mathrm{C}, P=160 \mathrm{P}$, in the environment vol. $\% \mathrm{~N} 2+96$ vol.\% Ar, $\tau=240 \mathrm{~min}$, using an Optimal SRV friction machine according.

The results of studies of the wear resistance of the BT8 alloy are given in table. 2. Studies show that the grip strength of titanium alloy after glow discharge in glow discharge in these test conditions has increased by almost 4.6 times, compared to the non-nitrided sample. The maximum permissible pressure on the friction surface increased by 3.7 times. 
The results of studies on the wear of steam nitricated titanium alloy VT8 - ball steel ShX15 machine Optimal SRV

\begin{tabular}{|c|c|c|c|c|c|c|}
\hline \multirow[b]{2}{*}{ Samples } & \multirow{2}{*}{$\begin{array}{c}\begin{array}{c}\text { Force } \\
\text { clutching }\end{array} \\
F, \mathrm{~N}\end{array}$} & \multirow{2}{*}{$\begin{array}{l}\text { Pressure in the } \\
\text { clutching zone } \\
P, \mathrm{~N} / \mathrm{mm}^{2}\end{array}$} & \multicolumn{2}{|c|}{ Wear } & \multirow{2}{*}{$\begin{array}{c}\text { Diameter } \\
\text { clutching } \\
D, \mathrm{~mm}\end{array}$} & \multirow{2}{*}{$\begin{array}{l}\text { The width } \\
\text { of the wear } \\
\text { track } h, \mathrm{~mm}\end{array}$} \\
\hline & & & $\begin{array}{l}\text { balls } \\
\Delta m_{\kappa} \mathrm{mG}\end{array}$ & $\begin{array}{c}\mathrm{VT} 8 \\
\Delta m, \mathrm{mG}\end{array}$ & & \\
\hline The source & 65 & 18,4 & 0,1 & 12,0 & 1,85 & 4,0 \\
\hline Nitrided sample & 300 & 67,5 & 2,1 & 0,8 & 2,45 & 2,4 \\
\hline
\end{tabular}

From the table 2 shows that the wear of a non- nitrided titanium alloy is 15 times greater than that of nitrous. The wear of the hardened ball of ShH 15 steel, which works in a pair of friction as a counterfoil, on the contrary, is much smaller in a pair with a non- nitrided sample. At the same time, the surface of the quenched ball was smeared with a non- nitrided titanium alloy. In a pair of "nitrided VT8 - hardened ball" wear big balls because of wear nitrided VT8 products have high hardness $(\mathrm{HV}=600-750)$ and were in the process as an abrasive wear.

\section{Conclusions}

The above material shows the promise of the technology of low-temperature hydrogennitriding by glow discharge. This greatly expands the range of practical applications of titanium alloys.

Among the promising technologies that can be used to improve the wear resistance of friction pairs, which include parts made of titanium alloys, should be considered low-temperature hydrogen-nitriding in glow discharge. The use of low-temperature hydrogen - nitriding in the smoldering discharge precludes the growth of the base grain and hydrogen embrittlement of the surface.

The low-temperature temperature hydrogen - nitrided in glow discharge allows to increase the antiadhesive properties of titanium alloy in the friction pair "nitrated titanium alloy - hardened ShX 15 steel" in the conditions of dry friction in 4.2 times in comparison with the non-nitrated titanium alloy.

\section{References}

1. Ionic chemical heat treatment of alloys / Arzamasov BN Bratuhin AG, S. Eliseev, T. Panajoti. Moscow: Publishing House of the MSTU Bauman, 1999. - 400 (in Russian).

2.. Lahtin J. Physical processes during ion nitriding / J. Lahtin, J. Crimskiy / In. " Protective coatings on metals." Kyiv, 1968. MY. 2. - S. 225-229 (in Russian).

3. Pastukh I. Physico- Technical metal surface treatment without hydrogen nitriding in a glow discharge : dis. Doctor of. sciences: 05.03.07 / Pastukh Igor Markovic. - K., 2008. - 520 p. (in Ukrainian)

4. Kaplun VG Scientific bases of technology hardening machine parts and tools ion nitriding in hydrogen-free environments : dis. Doctor. tehn. Sciences: 05.02.01 / Vitaly G. Kaplun. - Khmelnitsky, 1992. 450. (in Russian).

5. Pastukh IM Theory and Practice of without hydrogen glow discharge nitriding / Igor Markovic Pastukh. - Kharkov: KIPT 2006. - 364.

6. Hladkyi Ya.M. Tribology of wear-resistant coatings / Ya.M. Hladkyi, O.M. Makovkin, S.S. Bys / Bulletin of Khmelnitsky National University. - 2005, №5. - T.2.-c. 19-23. 
Машовець Н.С. Аналіз впливу азотування в тліючому розряді на властивості титанового сплаву.

Ця робота присвячена результатам низькотемпературного азотування в тліючому розряді для розробки рекомендацій щодо подальшого практичного застосування. Модифікація поверхні титанових сплавів проводилася низькотемпературним азотуванням в тліючому розряді в без водневому середовищі. Основна перевага цього методу полягає у відсутності водневого окрихчування та повноцінного екологічного безпечного процесу. Застосування тліючого розряду дозволяє не тільки прискорити процес дифузійного насичення поверхні азотом, але й істотно змінить кінетику процесу та якість азотованого шару, зокрема його фізико-механічні властивості та фазовий склад.

Ключові слова: титановий сплав, азотування в тліючому розряді, тертя та зношування. 